\title{
Editorial
}

\section{Whither the book?}

The prophets of gloom and the champions of progress are never done trying to discourage or inspire us with their various prognostications. Surveys show that fewer books are being read and Libraries find their budgets are increasingly being eaten up by subscriptions to ever more expensive periodicals. With electronic publication, collective authorship may seem to replace the individual writer. Furthermore, there is not, as yet, any adequate control over the veracity and reliability of information put up on the Internet.

Yet the prophets of gloom cannot gainsay the advantages of the electronic book. It has been the dream of all libraries, since that of Alexandria, to have total coverage in their collection, a dream that would be inconceivable without the digitization of texts. Another dream now capable of being fulfilled is access by all to such texts - an access limited, in reality, by the availability of the necessary equipment and by the payment of service costs. Information can be constantly updated electronically. Service providers and service users can communicate interactively, both sending and receiving signals, as on cable TV. Such facilities are invaluable for teleshopping, teleworking and security. For scholars, the advantages of searchable text and the display of multiple versions of a given text are incalculable.

Fortunately, we are not in an 'either-or' situation. The book, as we know it, will endure, both as a means of preserving the heritage of the past and as something with which one would want to curl up in bed. Those who fear that the futuristic Bibliothèque nationale de France is an anachronistic temple to an outworn mode of communication are almost certainly worrying unnecessarily: between book conservation and book digitization, the balance there is probably about right. The merits of electronic publishing, bypassing the expense of book production and distribution, are evident in terms of the rapid and relatively costless dissemination of information. Equally evident, however, is the fact that a periodical that exists only in electronic form is less prestigious than one which is also available in hard copy, partly indeed because the very ease and low cost of putting material up on the Web (assuming one has access to the Web) is one of the reasons why electronic publications are generally not peer-reviewed. In a sense, the extreme cheapness of the production almost devalues the information thus disseminated. 
There are, however, deeper questions to be asked about the future of the book. Given that its form is changing, should we anticipate new forms of reading and writing? Experience would seem to suggest that such is the case.

It has often been pointed out that authors do not write books: they write texts which others transform into objects, which, in their turn, may be hand-written, engraved or printed - in various editions and formats, depending on the circumstances of the production of the work. All these elements can modify the reception of the original text, which is thus shown to be open and malleable, according to the circumstances of its readers. Texts are not deposited in objects (printed books), which contain them like receptacles.

Texts are, thus, not as monolithic as some would have us believe. They are not necessarily written in stone, although probably they first were. The transition from scrolls to codex form, as early as the second century AD, involved folding the parchment or papyrus in such a way as to sew a number of leaves together and enable the reader to absorb the text horizontally rather than vertically. This material change was, in time, to revolutionize the habits of reading and writing, since cross-referencing and pagination enhanced the potential of the future book as a resource.

Marshall McLuhan, in The Medium is the Massage (1967), goes back still further and traces the turning point to the invention of the phonetic alphabet. Prior to that, he claims, perception was primarily auditory, 'a projection of the right hemisphere of the human brain', a mental process that 'emphasizes the pattern-like qualities of qualitative thinking'. From this 'acoustic space', McLuhan maintains that the phonetic alphabet carried mankind forward to "visual space', 'which emphasizes the operation of the left hemisphere of the brain and which, in the process glorifies quantitative reasoning'. 'Visual space', in this view, characterized the mind-set of Western civilization, as it proceeded, over the last 4000 years, to fix its linear self-image. The process was gradual. Medieval manuscripts were meant to be read aloud and there was little stress on individual authorship. The Gutenberg invention of moveable type turned the book into a portable commodity and broke with its origins in orality. Punctuation came in the Middle Ages, but typography ushered in systematized language and grammar. With the mass dissemination of the book, in the fourteenth and fifteenth centuries, a sense of order was established around the private, fixed point of view, which was analogous to that of the newly-found sense of perspective in easel painting. With Renaissance Man, as has often been said, the concept of the author was born.

Further technological advances in printing and in the mass production of paper conferred a new status on the publisher in the early decades of the nineteenth century. Publishers, like art dealers, played a crucial role at the interface between writers, artists and their public. The individualism, born of the Renaissance, evolved into the nation-state; and the printed word enhanced the role of the book 
as a focus for uniformity within central government. In the cultural sphere, a literary 'canon' was established and methods of 'literary history' developed to apprehend it.

With the twentieth century, major fissures began to show. The innovations of Marconi and Edison gave a new sense to the power of the spoken word. James Joyce, in Finnegans Wake, celebrated the rupture of the ethos of print by radio, film and recording. Emerging media, such as the satellite, the computer or the database, shook the position of the printed word as the 'sole' purveyor of texts. The 'Gutenberg Galaxy', as adumbrated by McLuhan, was involved in a total reconfiguration, with the unseating of the book from its position at the pinnacle of authority. With the electronic age, a plurality of media has meant that the sequential, step-by-step approach of linear thought has been replaced by a simultaneous apprehension of multiple factors based on a variety of sense perceptions. In the words of McLuhan, the 'new technology' demands that we abandon the luxury of 'fixed points of view', with their concomitant 'fragmentary outlook' ${ }^{2}$ in favour of a more holistic, right-hemisphere approach.

At more or less the same time as McLuhan was tracing these changes in modes of perception, Roland Barthes and Michel Foucault (in 1968 and 1969 respectively) were proclaiming the death of the author. Rumours of this demise, as Mark Twain might have said, may well have been exaggerated, but the sidelining of the author had the effect of conferring a new status on the reader, without whose participation the mission embarked upon by the author was deemed to be incomplete. Stripped of roots in the life of the author, the text was, for Barthes, a tissue of quotations, a resonant chamber, in which references to other works functioned in a system of call and echo, which Julia Kristeva named 'intertextuality'. The reader was now to be the locus of all the unifying efforts previously attributed to the author and modern critical theory was born.

'New readers', as Donald McKenzie observed in his 1985 Panizzi lecture, 'make new texts, and their meanings are a function of their new forms'. In some ways, the scrolling up and down of a computer screen may be seen as a reversion to the predecessor of the codex, though one of a vast menu of forms rather than serving as the sole staple. Again, the screen as a support can bring many media together - the printed page, the hand-written journal, the diagram, the graph, the sketch, not to mention the drawing, the painting or the sculpture. The specificities of each are lost, but the simultaneous accessibility of all provides a level of integration far beyond the confines of the printed book. Both author and reader can avail of the holistic approach heralded by McLuhan. Hypertext, for example, breaks with the linear tradition of writing and reading, in favour of an open-ended process enabling direct consultation of the source-material of the topic in question. 'Footnotes' are replaced by 'links' in the realm of the virtual text, which straddles all frontiers. This is a good example of how a change in form can bring about 
epistemological change. The fact that material which previously appeared in different media, each with its own hierarchy, can now be uniformly accessed by screen has had an overall levelling effect and has opened up hitherto unimagined possibilities for future development.

Whither the book? The book, with all its tactile richness, whether as a sumptuous livre d'artiste or a dog-eared personal treasure, will continue to be an indispensable part of our lives. But the text may now take many and varied forms in our increasingly holistic mode of perception. Some of the old hierarchies have been shattered, as practical storage decisions by booksellers tend to show: 'Literature' is broken up into units, such as Drama, Poetry, Fiction, with 'World Classics' and 'Literary Theory' as categories in themselves. The author is, in a more deeply empowered sense, the writer. The reader can opt between an attitude of passivity and one of active involvement with the text. If the Gutenberg revolution gave us moveable type, the electronic revolution has given us moveable texts.

Barbara Wright, Trinity College, Dublin, Ireland

\section{References}

1. M. McLuhan and B. R. Power (1989) The Global Village:

Transformations in World Life and Media in the Twenty-first Century (New York, Oxford: Oxford University Press), p. ix.

2. M. McLuhan and Q. Fiore (1967) The Medium is the Massage (New York: Random House), pp. 68-69. 